\title{
The Role and Impact of the European Convention on Human Rights Beyond States Parties: The curious case of the ECHR in Kosovo $^{1}$
}

\author{
Beti Hohler and Barbara Sonczyk
}

\section{A. Introduction}

The European Convention on Human Rights and Fundamental Freedoms ('ECHR', 'the Convention') has defined human rights protection in Europe for over 70 years. ${ }^{2}$ Its supervisory mechanism - the European Court of Human Rights ('ECtHR', 'the Strasbourg Court') - has subsequently influenced the legal standards for administration of justice, safeguarding the protection of individuals against unfairness and the abuse of power, and upholding pluralistic democracy. ${ }^{3}$ The Convention has also impacted on the human rights discourse outside Europe, asserting its progressively transformative role in international legal landscape more broadly. ${ }^{4}$ Various UN bodies, other international organisations, regional courts, international criminal tribunals, national authorities and civil society institutions frequently reference the Convention and the case law of the Strasbourg Court in their work, extending the impact of the treaty regime well beyond the State Parties.

A unique example of such impact is Kosovo, a contested State on the Balkan peninsula and a former UN-administered territory, where the

1 All references to Kosovo in this text shall be understood to be in full compliance with United Nations Security Council Resolution 1244 (1999) and without prejudice to the status of Kosovo. The authors would like to thank HHJ Andrew Hatton, Dr. Mateja Peter and Njomza Haxhibeqiri for their comments on an earlier draft of this chapter.

2 Council of Europe (CoE), The European Convention on Human Rights. A living instrument, 2020, https://www.echr.coe.int/Documents/Convention_Instrument_E NG.pdf, 5.

$3 \mathrm{CoE}$, Report of the Evaluation Group to the Committee of Ministers on the European Court of Human Rights, 27 September 2001, EG Court (2001) 1, 2.

4 Dzehtsiarou and Tzevelekos, 'The Conscience of Europe that Landed in Strasbourg: A Circle of Life of the European Court of Human Rights' (2020) $1 \mathrm{ECH}$ $R L R, 1(1)$. 
Convention has been instrumental in the international rule represented by international organisations administering the territory or performing executive functions, the domestic legal system and, most recently, in the internationalised criminal court - the Kosovo Specialist Chambers - tasked with prosecuting international crimes. Kosovo's curious idiosyncratic legal framework enables us to study the role of the ECHR within a single territory from three different viewpoints: the contribution of the Convention to the paradigm of international governance and administration, the application of the Convention and Strasbourg case law in a non-State Party and the Convention's significance for war crimes prosecutions in an internationalised criminal court.

The chapter starts by providing a brief outline of the political history of Kosovo in section B to contextualise the ensuing discussion. Section $\mathrm{C}$ then elaborates on the process of introducing the Convention into Kosovo's legal system by the UN administration and its impact on the state-building efforts. This is followed by the analysis of the applicability - including its benefits and shortcomings - of the ECHR in Kosovo's legal order after its declaration of independence (Section D). The analysis discusses the legal status and significance of the case law of the ECtHR and the role of Kosovo courts, especially the Constitutional Court, in upholding human rights and fundamental freedoms guaranteed by the 2008 Kosovo Constitution. The main argument of the authors is that while the constitutionalisation of human rights treaties, in particular the ECHR, resulted in entrenching human rights in Kosovo's legal framework, which is in line with the Council of Europe (CoE)'s principle of subsidiarity and embeddedness, the protective system has its limitations since it is ultimately not supervised by the ECtHR. Section E uses the newly created Kosovo Specialist Chambers (KSC) and the Specialist Prosecutor's Office (SPO) to consider potential challenges within the Kosovo constitutional framework of human rights protection and further strengthens the argument about the need for a monitoring element to ensure full protection and compliance. The chapter concludes with remarks on the dynamic and evolving relationship between the ECHR and Kosovo. 


\section{B. Setting the Scene}

\section{Short Political History of Kosovo: from an Autonomous Province to Declaration of Independence}

After World War II, Kosovo was part of the Socialist Federal Republic of Yugoslavia. From 1974 on, it enjoyed the status of an autonomous province within the Republic of Serbia, ${ }^{5}$ one of Yugoslavia's six republics, until Serbia effectively revoked this status in 1989.6

From February 1998 until June 1999, an armed conflict between the army and police forces of the Federal Republic of Yugoslavia (i.e. Serbia and Montenegro) and the Kosovo Liberation Army (KLA), an armed group fighting for independence of Kosovo, took place in the territory of Kosovo. The conflict ended following the military intervention by NATO with the signing of the Military Technical Agreement between the International Security Force (KFOR) and the Governments of the Federal Republic of Yugoslavia and the Republic of Serbia on 9 June 1999.7 The latter paved the way for the deployment of civil and security forces in Kosovo. On 10 June 1999, the UN Security Council, acting under Chapter VII of the UN Charter, adopted Resolution 1244, which established the United Nations Interim Administration in Kosovo (UNMIK). The latter governed the territory until 2008. Whilst UNMIK remains operational to date, its day-to-day duties are significantly reduced. In 2008, UNMIK's rule of law tasks were transferred to a rule of law mission set up by the European Union - the EU Rule of Law Mission in Kosovo (EULEX) ${ }^{8}-$ which consisted of advisory and executive mandates. The executive mandate supported both the adjudication of civil justice and prosecution and adjudication of sensitive criminal cases (including war crimes). The Mission's judicial executive mandate came to an end in June 2018, and Kosovo assumed

5 Article 2 of the Constitution of the Socialist Federal Republic of Yugoslavia, 1974, https://www.worldstatesmen.org/Yugoslavia-Constitution1974.pdf.

6 For more about the history and dissolution of Yugoslavia, see e.g. Glenny, The Fall of Yugoslavia: The Third Balkan War (1996); Silber and Little, Yugoslavia: Death of a Nation (1997).

7 UN Security Council, Military-technical agreement between the international security force (KFOR) and the Governments of the Federal Republic of Yugoslavia and the Republic of Serbia, 15 June 1999, UN Doc. S/1999/682, 3 ff.

8 Council of the EU, Joint Action on the European Union Rule of Law Mission in Kosovo, 4 February 2008, 2008/124/CFSP. 
responsibility for all transferred investigations, prosecutions and trials, whilst the advisory component of the Mission remains. ${ }^{9}$

On 17 February 2008, Kosovo declared independence. The Declaration of Independence was an Act of the Assembly of Kosovo as an Interim Institution of Self-Government. The Constitution was enacted on 15 April 2008. According to Kosovo's Ministry of Foreign Affairs, as of September 2021 the territory has been recognised as an independent state by 117 countries. ${ }^{10}$ This includes 22 States of the European Union. ${ }^{11}$

In 2016, the EU signed the Stabilisation and Association Agreement (SAA) with Kosovo. The agreement does not constitute recognition of Kosovo as an independent State by the EU or individual EU countries. Its main aims are to support the efforts of Kosovo to strengthen democracy and the rule of law; contribute to political, economic and institutional stability in Kosovo and to the stabilisation of the region; to provide an appropriate framework for political dialogue and economic relations between the EU and Kosovo, including through aligning Kosovo's laws more closely to those of the EU and striving towards gradual development of a free trade area between the EU and Kosovo. ${ }^{12}$

Kosovo is not a member of the UN or the CoE. However, since 2009, it is a member of the International Monetary Fund and the World Bank. In 2014, Kosovo also joined two partial agreements of the CoE - the Development Bank and the European Commission for Democracy through Law (the Venice Commission).

9 Council of the EU, EULEX Kosovo: new role for the EU rule of law mission, 8 June 2018, https:/www.consilium.europa.eu/en/press/press-releases/2018/06/08/eulex-k osovo-new-role-for-the-eu-rule-of-law-mission/.

10 Ministry of Foreign Affairs and Diaspora of the Republic of Kosovo, International recognitions of the Republic of Kosovo, 2018, https://www.mfa-ks.net/en/politika/48 3/njohjet-ndrkombtare-t-republiks-s-kosovs/483 - last accessed on 27 September 2021.

11 As of September 2021 Spain, Slovakia, Cyprus, Romania, Greece have not recognized Kosovo.

12 Stabilisation and Association Agreement between the European Union and the European Atomic Energy Community, of the one part, and Kosovo of the other part, 16 March 2016, OJ EU L 71/3. 


\section{International Presence in Kosovo and the ECHR}

\section{Kosovo's Relationship with the ECHR: How it all Began}

The ECHR was introduced into Kosovo's legal system by UNMIK on 12 December 1999 with Regulation 1999/24 on applicable law which included the following clause:

In exercising their functions, all persons undertaking public duties or holding public office in Kosovo shall observe internationally recognized human rights standards, as reflected in particular in:

(a) The Universal Declaration on Human Rights of 10 December 1948;

(b) The European Convention for the Protection of Human Rights and Fundamental Freedoms of 4 November 1950 and the Protocols thereto;

(c) The International Covenant on Civil and Political Rights of 16 December 1966 and the Protocols thereto;

(d) The International Covenant on Economic, Social and Cultural Rights of 16 December 1966;

(e) The Convention on the Elimination of All Forms of Racial Discrimination of 21 December 1965;

(f) The Convention on Elimination of All Forms of Discrimination Against Women of 17 December 1979;

(g) The Convention Against Torture and Other Cruel, Inhumane or Degrading Treatment or Punishment of 17 December 1984; and

(h) The International Convention on the Rights of the Child of 20 December 1989. (emphasis added) $)^{13}$

This provision marks the beginning of Kosovo's relationship with the ECHR. Its immediate practical consequence was that UNMIK (and later EULEX) international judges and prosecutors deployed in Kosovo as members of international or mixed panels used the ECHR and its Protocols in their decisions both as a direct source of law and as a tool for interpreting the applicable law, causing the Convention to become an influential source of human rights standards in the territory. ${ }^{14}$ International judges

13 UNMIK, 'Regulation No. 1999/24 on the Law Applicable in Kosovo', 12 December 1999, https://unmik.unmissions.org/sites/default/files/regulations/02english/E 1999regs/RE1999_24.htm, section 1.3.

14 Between June 1999 and June 2018 international (first UNMIK and then EULEX) judges were embedded in the Kosovo domestic system and participated in adjudi- 
who were involved in the adjudication of cases and who also participated in capacity building were in practice an important force behind making the Convention known and applied in the territory, especially in the early years of international administration. Within EULEX, the vast majority of judges (and prosecutors) deployed in Kosovo came from European countries and were therefore familiar with the ECHR system and Strasbourg case law from their home jurisdictions.

In 2001, UNMIK and the Kosovo authorities adopted the 'Constitutional Framework for Provisional Self-Government in Kosovo', which further tied Kosovo's institutions - including the courts - to the Convention. The Framework explicitly stated that the Provisional Institutions of SelfGovernment must observe and ensure internationally recognized human rights and fundamental freedoms, including those rights and freedoms set forth in the ECHR and its Protocols. ${ }^{15}$

Thereafter, in 2007, an international commission was established to determine the status of Kosovo. It proposed a design for the prospective Kosovo State that would have to be mirrored in any future Constitution. This proposal - the Comprehensive Proposal for the Kosovo Status Settlement (informally known as the Ahtisaari Plan) - included the following provision:

Kosovo shall promote, protect and respect the highest level of internationally recognized human rights and fundamental freedoms, including those rights and freedoms set forth in the Universal Declaration on Human Rights, the International Covenant on Civil and Political Rights, and the European Convention for the Protection of Human Rights and Fundamental Freedoms and its Protocols. Kosovo shall take all necessary measures towards ratifying the European Convention for the Protection

cation of sensitive cases at all court levels and to different extents as time went on. The last cases to be transferred to the entirely local panels were war crimes cases following the end of EULEX's executive mandate in 2018, with the exception of cases falling within the specific jurisdiction of the KSC. The latter, as discussed in more detail bellow, exist within the Kosovo domestic court system and mirror the levels of Kosovo's courts of general jurisdiction (Basic Court, Court of Appeals, Supreme Court, Constitutional Court). See e.g. decisions with participation of EULEX judges: EULEX, Court Judgments, 2021, https://www.eulex-kosovo.eu/?pa ge $=2,8$.

15 UNMIK, 'A Constitutional Framework for Provisional Self-Government in Kosovo', Regulation No. 2001/9, 15 May 2001, https://unmik.unmissions.org/sites/defa ult/files/regulations/02english/E2001regs/RE2001_09.pdf, section 3.2. 
of Human Rights and Fundamental Freedoms and its Protocols (emphasis added). ${ }^{16}$

By singling out the ECHR, the Commission seemingly set out to tie any future Kosovo State to the ECHR. De Hert and Korenica observe that the Commission 'considered, inter alia, that binding Kosovo to the ECHR would serve as one of the most important international safeguards for domestic human rights protection. ${ }^{17}$

\section{UNMIK and EULEX Human Rights Review Mechanisms and Their Reliance on the ECHR}

Another link between the international intervention in Kosovo and the ECHR comes in the form of quasi-judicial mechanisms set up by UNMIK and EULEX to address complaints of human rights violations attributable to the respective mission. The need for such a review body was first highlighted by the Venice Commission in 2004, which described the immunity of UNMIK personnel as 'itself a human rights concern'. ${ }^{18}$ In 2006, UNMIK established the Human Rights Advisory Panel (HRAP) to examine alleged violations of human rights by the Mission. ${ }^{19}$ The Panel's mandate was limited to issuing recommendations to the Secretary General's Special Representative for their action. HRAP was composed of international human

16 UN Security Council, Letter Dated 26 March 2007 from the Secretary-General addressed to the President of the Security Council, Addendum, Comprehensive Proposal for the Kosovo Status Settlement, 26 March 2007, UN Doc. S/2007/168/Add.1, Article 2.1.

17 De Hert and Korenica, 'The New Kosovo Constitution and Its Relationship with the European Convention on Human Rights: Constitutionalization "Without" Ratification in Post-Conflict Societies', (2016) 76 ZaöRV, 143 (151 and footnote 25).

18 CoE, European Commission for Democracy Through Law (Venice Commission) Opinion on Human Rights in Kosovo: Possible Establishment of Review Mechanisms, 11 October 2004, CDL-AD (2004)033, paras. $62 \mathrm{f}$.

19 UNMIK, 'Regulation No. 2006/12 on the Establishment of the Human Rights Advisory Panel', 23 March 2006, https://unmik.unmissions.org/sites/default/files /regulations/02english/E2006regs/RE2006_12.pdf. See also e.g. Istrefi, 'Evolving International Practices for Protection of Human Rights - the UN Human Rights Advisory Panel and EU Human Rights Review Panel' (2017) 1 AUDJ, 60; Knoll and Uhl, 'Too Little, Too Late: the Human Rights Advisory Panel in Kosovo' (2007) 7 European Human Rights Law Review, 534. 
rights experts nominated by the President of the ECtHR. It was operational for 9 years (2007-2016) and dealt with a total of 527 complaints. ${ }^{20}$

The Panel relied heavily on the Convention and the jurisprudence of the ECtHR. This was to be expected given that the Convention was the applicable law in Kosovo and also listed amongst the Panel's sources of law. ${ }^{21}$ In some areas, the Panel extended the interpretations emanating from Strasbourg case law. This included issues like

the determination of legal standards in the context of investigating disappearances and killings where the wrongdoing was committed by non-state actors; the applicability of substantive protections of Article 2 of the ECHR to a UN body in the context of public protest; the applicability of Article 3 of the ECHR to a UN body involving violations with respect to the inhuman and degrading treatment of relatives of missing and/or murdered persons and the procedural aspect of Article 5 ECHR, taking into account the need for gender-sensitive investigations. $^{22}$

EULEX established a similar body in 2009, called the Human Rights Review Panel (HRRP). The Panel remains operational and has jurisdiction from 9 December 2008 onward. It is composed of three international experts in human rights law, appointed by the Head of EULEX Mission. The complaints filed before the Panel have predominately argued violations of the ECHR and its Protocols. ${ }^{23}$ Like its UNMIK counterpart, the Panel relies extensively on the Convention and ECtHR's jurisprudence.

20 UNMIK, 'The Human Rights Advisory Panel: History and Legacy, Kosovo, 20072016, Final Report, 30 June 2016, https://unmik.unmissions.org/sites/default/fi les/hrap_final_report_final_version_30_june_2016.pdf, para. 23. The Panel's temporal jurisdiction was limited to alleged violations of human rights that occurred between 23 April 2005 and 9 December 2008, when UNMIK's responsibility in the areas of justice and police in Kosovo was transferred to EULEX.

21 UNMIK, 'Regulation No. 2006/12 on the Establishment of the Human Rights Advisory Panel', 23 March 2006, https:/unmik.unmissions.org/sites/default/files/r egulations/02english/E2006regs/RE2006_12.pdf, section 1.2.

22 UNMIK, 'The Human Rights Advisory Panel: History and Legacy, Kosovo, 20072016, Final Report, 30 June 2016, https://unmik.unmissions.org/sites/default/files /hrap_final_report_final_version_30_june_2016.pdf, para. 136.

23 See Human Rights Review Panel, 'Annual Report', 2010, https://hrrp.eu/annual-r eport.php. 
According to available statistics, the Panel had - as of April 2020 - dealt with 201 cases, 177 of which have been finalised. ${ }^{24}$

\section{Current status of the ECHR in Kosovo: The Constitution and Beyond}

The second perspective that merits analysis is the applicability of the ECHR in the domestic legal order of Kosovo, a non-Signatory of the Convention. This section analyses the Kosovo Constitution, which provides a legal basis for the protection of the Convention rights and freedoms in the territory of Kosovo and the role of domestic courts, especially the Constitutional Court.

\section{Incorporation of the ECHR in the Constitution of the Republic of Kosovo}

Protection of human rights and freedoms is a central theme throughout the Kosovo Constitution, a legacy of the Ahtisaari Plan. As discussed in the previous section, one of the conditions for a prospective Kosovo State was to guarantee the protection and respect for 'the highest level of internationally recognized human rights and fundamental freedoms'. ${ }^{25}$ The natural way to achieve that would be to ratify the core human rights treaties and take on international obligations for their implementation. However, accession to international treaty regimes was not readily available for Kosovo, since entering into treaty arrangements is an expression of state sovereignty while Kosovo's sovereign status was (and remains) contested. Treaties bind consenting parties only, and third parties to any treaty are legally unaffected by it. ${ }^{26}$

The alternative way to bind Kosovo to human rights standards was to weave them into its domestic legal order. What the Constitution of Kosovo does, therefore, is to incorporate into Kosovo's legal system eight international agreements and instruments in order to form a single system

24 Human Rights Review Panel, 'Table of Cases with Follow-Up Decisions - April 2020, 2010', https://hrrp.eu/Statistics.php.

25 UN Security Council, Letter Dated 26 March 2007 from the Secretary-General addressed to the President of the Security Council, Addendum, Comprehensive Proposal for the Kosovo Status Settlement, 26 March 2007, UN Doc. S/2007/168/Add.1, Article 1.3.

26 This is the classic customary rule of pacta tertiis nec nocent nec prosunt - a treaty does not create either obligations or rights for a third party without its consent as codified in Article 34 of the Vienna Convention on the Law of Treaties. 
of protection. These agreements and instruments are the same as those introduced by UNMIK in Regulation 1999/24 with the exception of omitting the International Covenant on Economic, Social and Cultural Rights. In addition, the Council of Europe's Framework Convention for the Protection of National Minorities is included.

By virtue of Article 22 of the Kosovo Constitution, these treaties and instruments are afforded legal authority of constitutional rank, direct applicability and, in case of conflict, priority over provisions of domestic laws and other acts of public institutions. In addition, the Constitution also separately lists individual and collective human rights and freedoms, ${ }^{27}$ many of which mirror those enshrined in the Convention.

The constitutional status of the ECHR was specifically addressed by the Constitutional Court in its early case law, when it ruled that a violation of rights or freedoms protected under the Convention amounts to a constitutional violation..$^{28}$ This is an unprecedented example of the applicability of an international treaty in a Non-State Party and also the indication of reverence enjoyed by the Convention.

\section{The Status of ECtHR's Jurisprudence within Kosovo's Constitutional Framework}

Various commentators have addressed the issue of whether Article 22 of the Kosovo Constitution constitutionalises only texts of the enumerated international treaties or also the legal context ${ }^{29}$ in which they operate, such as jurisprudence of the ECtHR or authoritative interpretative comments issued by the relevant treaty monitoring bodies. ${ }^{30}$ Several observations can be made in this regard. Firstly, judgments of the ECtHR do not create law,

27 Chapter II and III of the Constitution of the Republic of Kosovo, 9 April 2008, https://gzk.rks-gov.net/ActDetail.aspx?ActID=3702.

28 Constitutional Court of Kosovo, Judgment, 23 June 2010, KI 40/09, Ibrahimi and 48 other former employees of the Kosovo Energy Corporation $v 49$ individual judgments of the Supreme Court of the Republic of Kosovo.

29 The term 'context' can be explained by reference to Article 31 of the Vienna Convention on the Law of Treaties.

30 E.g. Korenica and Doli, 'Taking Care of Strasbourg: The Status of the European Convention on Human Rights and the Case-Law of the European Court of Human Rights in Kosovo's Domestic Legal System' (2011) 32 Liverpool Law Rev, 209 (217); De Hert and Korenica, 'The New Kosovo Constitution and Its Relationship with the European Convention on Human Rights: Constitutionalization "Without" Ratification in Post-Conflict Societies', (2016) 76 ZaöRV, 143. 
as the norm of stare decisis does not exist in international law in the same way as it operates in common law systems. ${ }^{31}$ Secondly, the jurisprudence of the ECtHR does not have erga omnes effect on States Parties to the Convention; only a State that is party to the case is bound by the ECtHR's interpretation of the Convention and its findings on violations of the Convention. Thirdly, there is a separate provision in the Constitution of Kosovo - Article 53 - that specifically regulates the role (and status) of ECtHR case law, which 'does not constitutionalize or incorporate ECtHR case law into Kosovo's domestic legal order in the same way as Art. 22 constitutionalizes the ECHR'. ${ }^{32}$ Article 53 of the Kosovo Constitution, entitled 'Interpretation of Human Rights Provisions', instead stipulates that human rights and fundamental freedoms guaranteed by the Constitution shall be interpreted consistently with the decisions of the ECtHR. The reference to 'human rights and fundamental freedoms' guaranteed by the Constitution, without further specification, seems to encompass not just the human rights and freedoms explicitly listed in the Constitution but also rights covered by other international agreements and instruments listed in Article 22 of the Kosovo Constitution, including the ECHR and its Protocols. ${ }^{33}$ Notably, Article 53 of the Kosovo Constitution does not make any reference to pronouncements of other human rights treaty monitoring bodies, which suggests a uniquely strong position of the Convention and the Strasbourg Court. This is due to the special consideration enjoyed by the ECHR throughout Kosovo's state-building process (as discussed above) and the authority of the ECtHR more generally.

Article 53 of the Kosovo Constitution does not bind only courts, but also all public institutions and authorities in Kosovo that apply and interpret human rights provisions in their public service. This, in turn, suggests that the beneficiaries of the constitutional catalogue of human rights can demand to have them 'interpreted consistently with the court decisions' of the ECtHR. This, however, is not the same as to claim rights, freedoms or duties directly from the ECtHR jurisprudence. In other words, the ECtHR

31 Article 38(1)(d) and Article 59 of the Statute of the International Court of Justice.

32 De Hert and Korenica, 'The New Kosovo Constitution and Its Relationship with the European Convention on Human Rights: Constitutionalization "Without" Ratification in Post-Conflict Societies', (2016) 76 ZaöRV, 143 (159 and footnote 40).

33 Korenica and Doli, 'Taking Care of Strasbourg: The Status of the European Convention on Human Rights and the Case-Law of the European Court of Human Rights in Kosovo's Domestic Legal System' (2011) 32 Liverpool Law Rev, 209 (217). 
case law is not a source of law as such. ${ }^{34}$ The distinction may appear to be insignificant, but it is present and may play a role in litigation.

Commentators agree that Article 53 of the Kosovo Constitution does not make ECtHR case law directly applicable, but only imposes a constitutional obligation on courts and public institutions to follow ECtHR's interpretations of human rights and fundamental freedoms. ${ }^{35}$ Article 53 of the Constitution binds all courts, including the Constitutional Court. The latter has followed Article 53 in both substantive and procedural aspects of cases concerning claims of human rights violations as well as when exercising abstract jurisdiction over constitutionality of Kosovo laws. ${ }^{36}$

The final question in this regard relates to what being bound by ECtHR case law actually entails. Does the obligation of 'consistent interpretation' merely mean that courts must avoid contradicting or disregarding the jurisprudence of the Strasbourg Court, or are Kosovo courts compelled to justify their decisions involving constitutional human rights with reference to the reasoning of the ECtHR? The commentators rely on early judgments of the Constitutional Court to suggest that the Court considered itself obliged to refer to ECtHR case law constitutionally but not bound by its rulings. ${ }^{37}$ In other words, the Court has viewed ECtHR's case law 'as a tool for advancing the interpretation of constitutional provisions, rather than as an obligation requiring adherence to ECtHR precedents'. ${ }^{38}$ Such approach allows the Court to treat ECtHR's standards as the floor rather than the ceiling of human rights protection and enables it to offer a broa-

34 De Hert and Korenica, 'The New Kosovo Constitution and Its Relationship with the European Convention on Human Rights: Constitutionalization "Without" Ratification in Post-Conflict Societies', (2016) 76 ZaöRV, 143 (159f.).

35 Korenica and Doli, 'Taking Care of Strasbourg: The Status of the European Convention on Human Rights and the Case-Law of the European Court of Human Rights in Kosovo's Domestic Legal System' (2011) 32 Liverpool Law Rev, 209 (218).

36 Constitutional Court of Kosovo, Decision, 16 October 2009, KI 11/09, Tomë Krasniqi v RTK et Al.

37 See e.g., Constitutional Court of Kosovo, Judgment, 23 June 2010, KI 40/09, Ibrahimi and 48 other former employees of the Kosovo Energy Corporation $v 49$ individual judgments of the Supreme Court of the Republic of Kosovo; Constitutional Court of Kosovo, Decision, 21 June 2010, KI 68/09, Emrush Kastrati v Decision of the Supreme Court of Kosovo, Pkl. No. 120/0; Constitutional Court of Kosovo, Judgment, 30 October 2010, KI 06/10, Valon Bislimi v Ministry of Internal Affairs, Kosovo Judicial Council and Ministry of Justice.

38 De Hert and Korenica, 'The New Kosovo Constitution and Its Relationship with the European Convention on Human Rights: Constitutionalization "Without" Ratification in Post-Conflict Societies', (2016) 76 Zä̈RV, 143 (162). 
der interpretation of constitutional rights. This judicial independence is not unusual, as constitutional courts of other states that have incorporated the Convention into their constitutions have adopted a similar stance. ${ }^{39}$

Incorporating the ECHR with all its Protocols into a domestic legal order and constitutionalising the obligation of public authorities to interpret human rights and fundamental freedoms consistently with the ECtHR's jurisprudence is an example of embedding the Strasbourg Court's supervisory system, which enables international human rights norms to infiltrate domestic legal and political processes and improve the prospects of compliance. As noted by one author,

$[w]$ hen Strasbourg rights and freedoms are fully domesticated in one of these ways, compliance with international law and national law approaches convergence. Stated differently, to the extent that a state accepts the rule of law at home, it also necessarily adheres to the rule of law internationally. ${ }^{40}$

This process is even more interesting and significant in the case of Kosovo: due to its contested statehood it is neither a member of the UN nor of the $\mathrm{CoE}$ and is not a party to any of the human rights treaties incorporated in its Constitution and, thereby, in fact, is free from any international obligation to implement them.

\section{Judicial Protection of Human Rights and Fundamental Freedoms within the Kosovo Legal System}

The non-participation of Kosovo in external mechanisms of monitoring and supervision of human rights implementation puts emphasis on the domestic oversight apparatus. The Constitution of Kosovo, in Article 54, provides for general guarantees such as recourse to courts in case of alleged violation of rights guaranteed by any law. The right to an effective legal remedy is further elaborated in Article 102 of the Kosovo Constitution. Moreover, Article 113 of the Kosovo Constitution envisages an individual complaint mechanism before the Constitutional Court in cases of violation of human rights specifically and the possibility for regular courts to

39 Examples include the German Constitutional Court and the Polish Constitutional Tribunal.

40 Helfer, 'Redesigning the European Court of Human Rights: Embeddedness as a Deep Structural Principle of the European Human Rights Regime' (2008) 19 EJIL, 125 (133). 
refer cases to the Constitutional Court if uncertain about the compatibility of any particular law with the Constitution.

\section{The Constitutional Court}

The Constitutional Court of Kosovo, established in January 2009, ${ }^{41}$ has played a decisive role in the development of the rule of law and the protection of human rights and fundamental freedoms in Kosovo. ${ }^{42}$

The legal basis for the organisation and functioning of the Constitutional Court stems from Chapter VIII of the Constitution and the Law on the Constitutional Court of the Republic of Kosovo (Law No. 03/L-121), supplemented by Rules of Procedure (No. 01/2018). ${ }^{43}$ The Constitutional Court is an independent organ in protecting the constitutionality and is the final interpreter of the Constitution. ${ }^{44}$ Article 113 specifies matters within the Constitutional Court's jurisdiction and the parties allowed to make referrals. It is authorised to review the legality of legislative and executive actions, pronounce on the constitutional compatibility of legislation, assess individual complaints of violations by public authorities of human rights and fundamental freedoms guaranteed by the Constitution and clarify the meaning of constitutional provisions. Decisions of the Constitutional Court are binding on the judiciary and all persons and institutions of the Republic of Kosovo. ${ }^{45}$ All acts rendered to be unconstitutional by the Constitutional Court lose their legal force.

41 Constitutional Court of Kosovo, Annual Report 2009, 20 December 2009, https:// gjk-ks.org/wp-content/uploads/2017/11/RaportiVjetor2009Final_ANG.pdf.

42 Hasani, 'The Role of the Constitutional Court in the Development of the Rule of Law in Kosovo' (2018) 43 RCEEL, 274 (312).

43 The work of the Court is further governed by the Constitutional Court of the Republic of Kosovo Code of Judicial Conduct, 19 June 2013, (https://gjk-ks.org/ en/the-constitutional-court/legal-base/code-of-judicial-conduct/gjkk_kodi_i_m iresjelljes_per_gjyqtare_ang-2/), the Regulation of the Legal Unit No. 03/2019, 2 December 2019, https://gjk-ks.org/wp-content/uploads/2019/12/Rregullore-0 3_2019_e-Njesis-Ligjore_eng.pdf, and the Practice Direction No. 06/2012 on Functioning and Structure of Legal Unit, 4 December 2012, https://gjk-ks.org/wp -content/uploads/2017/11/Practice_Direction_Legal_Unit_No.06-2012-1.pdf.

44 Article 4 of the Constitution of the Republic of Kosovo.

45 Article 116 [Legal Effect of Decisions] of the Constitution of the Republic of Kosovo. 
The Constitutional Court is independent from other institutions in its decision making and operation. ${ }^{46}$ It is composed of nine judges elected for a non-renewable mandate of nine years. ${ }^{47}$ Initially, in line with the former Article 152 of the Constitution, three out of nine judges were international judges appointed by the International Civilian Representative, upon consultation with the President of the ECtHR. This mechanism was intended to further emphasise the special status of the ECHR within Kosovo's legal order and to secure the application of the Convention and the ECtHR's jurisprudence. ${ }^{48}$ Since 2018, the Constitutional Court is composed exclusively of Kosovo judges. It deliberates as a panel composed of all judges who are present (a quorum requires seven judges) and decides by a majority of votes from the judges present and voting. ${ }^{49}$

\section{Individual Referrals}

Pursuant to Article 113(7) of the Constitution and procedure provided in Law No. 03/L-121, individuals may refer to the Constitutional Court violations of their constitutional rights and freedoms committed by public authorities. $^{50}$ They may submit a referral only after having exhausted all legal remedies provided by law and within four months from a final court decision in their case, public announcement of a contested decision or act, or entry into force of the challenged law. A referral shall specify what rights and freedoms are claimed to have been violated and what act of public authority is contested. If the Court determines that the challenged

46 Articles,106, 107 and 112(2) of the Constitution of the Republic of Kosovo; Articles 2, 5 and 10 of the Law No. 03/L-121 on the Constitutional Court of the Republic of Kosovo, Official Gazette of the Republic of Kosovo No. 46/2009, 15 January 2009, 4; Rule 2 of the Rules of Procedure of the Constitutional Court of the Republic of Kosovo, No. 01/2018, 13 June 2018, https://gjk-ks.org/wp-content/ uploads/2018/06/rregullore_e-_punes_gjkk_ang_2018.pdf.

47 Pursuant to Article 114 of the Kosovo Constitution, national judges are appointed by the President of the Republic of Kosovo upon the proposal of the Assembly of Kosovo. See also Article 4 of the Law No. 03/L-121 for other conditions of appointment.

48 Korenica and Doli, 'Taking Care of Strasbourg: The Status of the European Convention on Human Rights and the Case-Law of the European Court of Human Rights in Kosovo's Domestic Legal System' (2011) 32 Liverpool Law Rev, 209 (220).

49 Article 19 of Law No. 03/L-121.

$50 I d$., Articles 46 ff. 
decision violated the Constitution, it declares the decision void and may remand it to the issuing authority for reconsideration. ${ }^{51}$

During the first eleven years of its existence (2009-2020), the Constitutional Court received almost two thousand applications. Based on statistics available in the Constitutional Court's newsletters for years 2015-2020, the majority of the applications (between $70 \%$ and $90 \%$ each year) were triggered by individual complaints from natural persons alleging violations of their constitutional rights. Most of those complaints referred to violations allegedly committed through decisions of the regular courts - from $75 \%$ to $95 \%$ depending on the year with the rest referring to decisions of other public authorities. A large majority were rejected as inadmissible (between $75 \%$ and $80 \%) .52$ With regard to the alleged constitutional rights violated the most commonly referred were Equality Before the Law (Article 24 of the Kosovo Constitution) and Right to Fair and Impartial Trial (Article 31 of the Kosovo Constitution). When adjudicating the cases on the merits, the Court regularly refers to individual rights listed in Chapter II of the Kosovo Constitution and corresponding rights in the ECHR. ${ }^{53}$

The referrals to the Constitutional Court mirror the experience of constitutional courts in other European states, with the vast majority of cases also originating from complaints about individual constitutional rights. ${ }^{54}$ Most European constitutional courts accept the ECtHR as the interpretative authority on the Convention, rely extensively on its case law and adopt the technique of the harmonious interpretation of the ECHR when adjudicating individual referrals. ${ }^{55}$ This connection between domestic constitutional law and the Convention as interpreted by the Strasbourg Court 'has resulted in a better protection of fundamental rights in the European legal space'. ${ }^{56}$ Since Kosovo remains outside the formal treaty regime of the ECHR, the Constitutional Court had to take over as a domestic version of the ECtHR, embodying its ethos.

51 Rule 46 of the Rules of Procedure of the Constitutional Court of the Republic of Kosovo.

52 For conditions of admissibility see Article 113(7) of the Kosovo Constitution and Articles 46 ff. of Law No. 03/L-121.

53 Constitutional Court of Kosovo, Newsletter, 2021, https://gjk-ks.org/en/publicatio n_category/newsletter/.

54 Van de Heyning, 'Constitutional Courts as Guardians of Fundamental Rights. The constitutionalisation of the Convention through domestic constitutional adjudication', in: Popelier et al. (eds), The Role of Constitutional Courts in Multilevel Governance (2012), 19 (22).

55 Id., 28.

56 Id., 24. 
It is with the support of international actors, the $\mathrm{CoE}$ in particular, that the Constitutional Court is able to act as a guardian of human rights and fundamental freedoms. The $\mathrm{CoE}$ has assumed an active role in strengthening the capacity of the Constitutional Court through various projects. Since 2014, it has launched two tailored programmes aimed at 'ensuring the protection of individual human rights and fundamental freedoms through effective application of European human rights standards to individual complaints'. ${ }^{57}$ The projects targeted the judges and legal advisors of the Constitutional Court of Kosovo and, inter alia, offered a mentoring scheme for judges by peers from leading European constitutional courts and the ECtHR. The objective was to exchange the experiences of applying the ECHR and share best working methods. The programmes also provided working visits of Kosovo judges to the ECtHR and work placements in the Registry of the ECtHR for legal advisors to advance their professional development. It also supported professional exchanges between the Constitutional Court and the Venice Commission. Other activities coordinated by the CoE have been directed at raising awareness about European human rights standards and the work of the Constitutional Court amongst legal professionals and the general Kosovo population. ${ }^{58}$

\section{Strengthening the Domestic Capacity to Implement Human Rights and Fundamental Freedoms in accordance with the Principle of Subsidiarity}

The projects discussed above are elements of a broader assistance strategy for Kosovo. The international community has supported democracy and institution building in Kosovo ever since 1999, in compliance with the UN Security Council Resolution 1244. The CoE, in particular, has implemented several programmes to promote good governance, rule of law and human rights standards in Kosovo. These include the EU/CoE joint projects aimed at combating economic crime, promoting human rights, minority protection and local democracy in Kosovo. ${ }^{59}$ The CoE's office in Pristina provides vital assistance in the implementation of all

$57 \mathrm{CoE}$, Improving the protection of European Human Rights Standards by the Constitutional Court of Kosovo, 2020, https:/www.coe.int/en/web/national-impl ementation/kosovo-improving-the-protection-of-european-human-rights-standard s-by-the-constitutional-court-of-kosovo.

58 Ibid.

59 For more information see CoE, Kosovo*, 2020, https://www.coe.int/en/web/progr ammes/kosovo. 
co-operation activities, facilitating the delivery of support programmes and co-ordinating efforts of local and international actors. ${ }^{60}$ Several cooperation activities in the fields of judicial reform and human rights protection have been implemented to improve the day-to-day functioning and quality of Kosovo's justice system. ${ }^{61}$

Bolstering domestic remedies provided to individuals whose rights have been violated is in line with the principle of subsidiarity upon which the Strasbourg supervisory system is founded. States Parties to the ECHR bear the primary responsibility for guaranteeing human rights and fundamental freedoms enshrined in the Convention, while the ECtHR and other institutions of the CoE play a subsidiary and supplementary role. ${ }^{62}$ The principle of subsidiarity is embodied in the provisions of the Convention such as the obligation on Member States to provide an effective national remedy ${ }^{63}$ or the requirement to exhaust all domestic remedies. ${ }^{64}$ It serves as a cornerstone of the margin of appreciation doctrine referred to in the ECtHR's jurisprudence, and it explains the Court's refusal to supplant national protective mechanisms, act as a first instance fact-finder ${ }^{65}$ or a fourth-instance appeal of national court rulings. ${ }^{66}$ The principle of subsidiarity is explicitly referred to in the preamble of Protocol No. 16 to the ECHR, which extends the Court's competence to give advisory opinions to further enhance the interaction between the Court and national

60 See CoE, Welcome to the Council of Europe Office in Pristina, 2020, https://www .coe.int/en/web/pristina/home.

61 An overview of activities 2013-2020 is available on https:/www.coe.int/en/web/pr ogrammes/kosovo.

62 Arai-Takahashi, The Margin of Appreciation Doctrine and the Principle of Proportionality in the Jurisprudence of the ECHR (2002), $235 \mathrm{f}$.

63 Article 13 ECHR.

64 Article 35 ECHR.

65 The Court rarely and reluctantly takes on the role of a first-instance tribunal of fact, unless this is rendered unavoidable by the circumstances of a particular case when the Court is confronted with repeated allegations of flagrant violations and the lack of cooperation from the governments. See Harmsen, 'The European Convention on Human Rights After Enlargement' (2001) 5 Int'l J Human Rts, 18 (29).

66 Helfer, 'Redesigning the European Court of Human Rights: Embeddedness as a Deep Structural Principle of the European Human Rights Regime' (2008) 19 EJIL, 125 (128). See also ECtHR, Practical Guide on Admissibility Criteria, 30 April 2020, https://www.echr.coe.int/documents/admissibility_guide_eng.pdf. 
authorities and thereby reinforce implementation of the Convention in a domestic setting. ${ }^{67}$

The principle of subsidiarity rests on the premise that national authorities are better placed to protect individual human rights in their specific social and political context because they benefit from a comprehensive understanding of constitutional traditions of their nation, the values of their local culture, institutional and social practices as well as more complete factual information to make a decision at the closest level to the affected person as is effectively possible. ${ }^{68}$ Considerations of judicial expediency and efficiency further substantiate the primacy of domestic judicial review mechanisms. ${ }^{69}$ National choices of Convention-compatible implementation measures might also enjoy more institutional legitimacy than resolutions of supranational entities distant from people affected by such decisions.

The principle of subsidiarity seeks to balance the idea of non-interference and that of intervention or assistance, which implies that such interventions may sometimes be necessary. ${ }^{70}$ As a supervisory ancillary mechanism, the ECtHR can be utilised whenever national authorities prove less capable of ensuring the adequate protection of human rights due to a lack of necessary experience and expertise, or simply when they wilfully violate these rights. The right of individual petition is the linchpin of the Convention's supervisory framework, and the ECtHR is a permanent court with compulsory jurisdiction over all Member States to which individuals have direct access. ${ }^{71}$ The Convention's judicial review mechanism is a powerful tool and a necessary element of the CoE's entire control machi-

67 Protocol No. 16 to the ECHR, Preamble. The Protocol allows the highest courts and tribunals of State Parties to request the Strasbourg Court for advisory opinions on questions of principle relating to the interpretation or application of the rights and freedoms defined in the Convention or the protocols thereto. The Protocol entered into force on 1 August 2018.

68 Carozza, 'Subsidiarity as a Structural Principle of International Human Rights Law' (2003) 97 Am. J. Int'l L., 38 (72 f.).

69 Arai-Takahashi, The Margin of Appreciation Doctrine and the Principle of Proportionality in the Jurisprudence of the ECHR (2002), $235 \mathrm{f}$.

70 Carozza, 'Subsidiarity as a Structural Principle of International Human Rights Law' (2003) 97 Am. J. Int'l L., 38 (79).

71 Protocol No. 11 to the ECHR restructured the control machinery established thereby. See also the reaffirmation by Member States of the right to individual petition as the cornerstone of the ECHR control system in CoE, High Level Conference on the Future of the European Court of Human Rights, Declaration, 27 April 2011, https://echr.coe.int/Documents/2011_Izmir_FinalDeclaration_EN G.pdf, 3. 
nery offering 'individual justice' in situations where national mechanisms of human rights protection prove inadequate.

Kosovo has made progress towards human rights sensitive good governance. However numerous challenges remain. According to the European Commission (EC) 2020 Report, Kosovo is still at an early stage of developing a well-functioning judicial system. The administration of justice remains slow and inefficient while rule of law institutions need sustained efforts to build up their capacities. ${ }^{72}$ The EC notes that although the legal framework broadly guarantees the protection of human and fundamental rights in line with European standards, the implementation of human rights legislation and strategies is often undermined by inadequate resources, particularly at the local level, and limited political prioritisation. There is a large dependency on foreign donors. ${ }^{73}$ Oversight and coordination of existing human rights mechanisms remain a challenge. ${ }^{74}$ According to the Civil Society Report on Human Rights in Kosovo in 2019, there is also an existing gap in joint reporting on human rights at the local and international levels..$^{75}$ The conclusions of these reports explain the structure of referrals to the Kosovo Constitutional Court, which as discussed above, are mostly composed of individual referrals alleging violations of constitutional rights committed by lower courts or public institutions. All this suggests that Kosovo would benefit from the CoE's multifaceted control machinery, including the oversight of the ECtHR, to improve the promotion and protection of human rights. However, until it becomes a member of the organisation and a State Party to the ECHR, these monitoring and enforcement measures remain unavailable.

72 European Commission, Commission Staff Working Document, Kosovo* 2020 Report, 6 October 2020, SWD(2020) 356 final, $17 \mathrm{f}$.

73 Id., 6.

74 Id., 29.

75 Office of the UN High Commissioner for Human Rights, Civil Society Report on Human Rights in Kosovo in 2019, June 2020, https://www.ohchr.org/Documents/ Press/kosovo_cso_2019_human_rights_report_en.pdf. The report was delivered at the conclusion of the project called 'Engaging with civil society on human rights monitoring and reporting' funded by the Human Rights Component of UNMIK and the OHCHR. 


\section{E. Beyond the Constitution - the ECHR as a Directly Applicable Source of Law for the Kosovo Specialist Chambers}

The third example of multifaceted impact of the ECHR is the direct applicability of the Convention to war crimes prosecutions conducted by an internationalised court. Again, Kosovo serves as a laboratory for this exploration. By virtue of its position and role in the Kosovo Constitution, the ECHR is now also a directly applicable source of law for the newly established internationalised criminal tribunal - the Kosovo Specialist Chambers (KSC) and the Specialist Prosecutor's Office (SPO).

The KSC are a unique model of a temporary internationalised criminal court existing within the domestic justice system. ${ }^{76}$ They are not, however, the first international(ised) mechanism established in/for Kosovo to prosecute crimes committed during the Kosovo War; there has been the ICTY and the participation of international judges and prosecutors in Kosovo proceedings under the UNMIK and EULEX umbrella. ${ }^{77}$

\section{Legal Framework of the KSC}

The KSC and the SPO were created in 2015 pursuant to an exchange of letters between the EU High Representative and the President of Kosovo ratified by the Kosovo Assembly, ${ }^{78}$ a Constitutional Amendment (Article 162 of the Kosovo Constitution $)^{79}$ and the Law on Kosovo Specialist Chambers and Specialist Prosecutor's Office (Law No. 05/L-053).80 They are funded by EU Member States and Third Contributing States and their seat is in the Hague. The KSC became fully judicially operational in July

76 Korenica et al., 'The EU-engineered hybrid and international specialist court in Kosovo: how "special" is it?' (2016) 12 EuConst, 474 (474).

77 Williams, 'The Specialist Chambers of Kosovo The Limits of Internationalization?' (2016) 14 JICJ, 25 (31).

78 Law No. 04/L-274 on Ratification of the International Agreement between the Republic of Kosovo and the Eureopan Union Role of Law Mission in Kosovo, Official Gazette of the Republic of Kosovo No. 32/2014, 15 May 2014, 4.

79 Amendment of the Constitution of the Republic of Kosovo, No. 05-D-139, 3 August 2015, Official Gazette of the Republic of Kosovo No. 20/2015, 5 August 2015, 4.

80 Law No. 05/L-053 on Specialist Chambers and Specialist Prosecutor's Office, Official Gazette of the Republic of Kosovo No. 27/2015, 31 August 2015, 1. 
2017 while the first indictments were confirmed in $2020 .{ }^{81}$ The first trial opened in September 2021.

The KSC exercise jurisdiction over crimes against humanity, war crimes and serious crimes under Kosovo law, which were committed (or whose commission began) in Kosovo between 1 January 1998 and 31 December 2000 by or against citizens of Kosovo or the former Republic of Yugoslavia, as well as certain crimes against the administration of justice. ${ }^{82}$ Its subject matter jurisdiction is limited to crimes purportedly committed by high-level members of the KLA during and shortly before/after the war in Kosovo, described in the 2010 Report of Special Rapporteur Dick Marty to the Parliamentary Assembly of the Council of Europe. ${ }^{83}$ The institution will exist only for as long as necessary to deal with charges presented by the Specialist Prosecutor and until the EU Council is satisfied that investigations and proceedings are completed.

Some commentators have suggested that Article 162 of the Kosovo Constitution establishing the KSC and SPO has created 'a parallel self-contained regime within the Constitution whose authority is independent of the rest of the Constitution' ${ }^{84}$ The provision opens with a caveat ('Notwithstanding any provision in this Constitution'), which has been viewed as an autonomous source of authority to operate the special(ist) court. ${ }^{85}$ This autonomy can be seen in the structure of the KSC and the applicable law. While the KSC are part of the existing judicial framework in Kosovo and accordingly have the same court levels (a Basic Court Chamber, a Court of Appeals Chamber, a Supreme Court Chamber and a Constitutional Court Chamber), they employ exclusively international staff, 86 are granted primacy over all other courts in Kosovo in relation to the crimes within the KSC's jurisdiction and are fully independent in the fulfilment of their mandate and work. ${ }^{87}$ The Specialist Constitutional Court Chamber is composed of three constitutional judges assigned from

81 See Kosovo Specialist Chambers \& Specialist Prosecutor's Office, 2021, https://ww w.scp-ks.org/en.

82 Law No. 05/L-053, Chapter III (Jurisdiction and Applicable Law of the Law on Specialist Chambers and Specialist Prosecutor's Office).

$83 \mathrm{CoE}$ Parliamentary Assembly, Inbuman treatment of people and illicit trafficking in human organs in Kosovo, AS/Jur (2010) 46, 12 December 2010.

84 Korenica et al., 'The EU-engineered hybrid and international specialist court in Kosovo: how "special" is it?' (2016) 12 EuConst, 474 (482).

85 Ibid.

86 For a general discussion on international, hybrid and internationalised courts see: Williams, Hybrid and Internationalised Criminal Tribunals (2012).

87 Law No. 05/L-053, Article 10(1). 
the KSC Roster of International Judges, ${ }^{88}$ and it deals exclusively with constitutional referrals relating to the KSC and $\mathrm{SPO}^{89}$ and is the final authority for the interpretation of the Constitution in this regard. ${ }^{90}$

Law No. 05/L-053 lists relevant sources of law for the KSC as follows: the Law itself, the Constitution, other provisions of Kosovo law as expressly incorporated and applied by Law No.05/L-053, customary international law, as given superiority over domestic laws by Article 19(2) of the Constitution, and international human rights law that sets criminal justice standards, including the European Convention on Human Rights and Fundamental Freedoms and the International Covenant on Civil and Political Rights, as given superiority over domestic laws by Article 22 of the Constitution. ${ }^{91}$ The Law also provides that any other Kosovo law, regulation, secondary regulation, other rule or custom and practice which has not been expressly incorporated into it, is not applicable and that the Law prevails over any and all contrary provisions of other laws or regulations. ${ }^{92}$

\section{Implications of the Legal Framework of the KSC}

In light of the above discussion, the following observations can be made: Firstly, the ECHR is a direct source of law for the KSC and will guide the Specialist Prosecutor and the Judges, in particular in relation to fair trial and detention issues and criminal justice more broadly. The KSC jurisprudence may consequently inspire or assist other international, hybrid or internationalised criminal courts not explicitly bound by the ECHR, thereby further extending the reach of the Convention.

Secondly, the self-contained regime of the KSC, as established by the amended Article 162 of the Constitution and the Law No. 05/L-053, insulates the decisions of the KSC and the SPO from any review of the Kosovo institutions outside of its structure. Additionally, since Kosovo is not a member of the CoE and not a State Party to the ECHR, decisions of the KSC remain outside the control of the ECtHR or any political or expert body of the CoE. ${ }^{93}$

88 Id., Article 25(1)(e).

$89 I d$., Articles 3(1), 49(2).

90 Id., Article 49.

91 Id., Article 3(2).

92 Id., Article 3(4).

93 Korenica et al., 'The EU-engineered hybrid and international specialist court in Kosovo: how "special" is it?' (2016) 12 EuConst 2016, 474 (484f.). 
Thirdly, the Specialist Constitutional Court Chamber is the final arbiter of constitutional referrals and the final interpreter of the Kosovo Constitution in relation to the subject matter, jurisdiction and work of the KSC and the SPO, which would also include human rights issues. Despite being part of the Kosovo Constitutional Court, the Specialist Constitutional Court Chamber is at the same time distinct from it in size and personnel. As explained above, it is composed of three international judges as opposed to nine national judges of the Constitutional Court. The KSC are bound only by the Constitution and other laws explicitly acknowledged in the Law No. 05/L-053, which are only one segment of the mosaic of the Kosovo domestic legal order. The Kosovo Constitutional Court, on the other hand, interprets constitutional provisions in a wider context of the text and acquis of entire national law and emerging national constitutional identity. Whether these differences will be problematic remains to be seen, although there has already been an indication. In its first judgment of 26 April 2017, ${ }^{94}$ tasked with reviewing the constitutionality of the Rules of Procedure (RoP), the Specialist Constitutional Court Chamber in The Hague declined to evaluate Rule 134(3) RoP holding that it was 'not in a position to rule that this provision complies with Chapter II [Fundamental Rights and Freedoms] of the Constitution'. ${ }^{95}$ By relying on the doctrine non liquet (i.e. not clear), it disregarded the rich jurisprudence of the Constitutional Court in Pristina. ${ }^{96}$ Moreover, this stance of the Specialist Constitutional Court Chamber is not the standard practice of European constitutional courts, which would only exceptionally declare themselves unable to rule on an issue. ${ }^{77}$ There are two speculative implications of such an approach. First, the Specialist Judges may ignore the rich case law of the Constitutional Court in Pristina with regard to other issues as well, including fundamental rights and freedoms. Second, it is not clear whether the Constitutional Court and other courts in Kosovo will follow or even consider the judgments of the Specialist Constitutional Court Chamber, for example in relation to criminal justice standards. This may

94 KSC, Judgment (Specialist Chamber of the Constitutional Court), 26 April 2017, Specialist Chamber of the Constitutional Court, Referral of the Rules of Procedure and Evidence Pursuant to Article 19(5) of the Law, KSC-CC-PR-2017-01, paras. $190 \mathrm{ff}$.

95 Id., para. 193.

96 Hasani and Mjeku, 'International(ized) Constitutional Court: Kosovo's Transfer

97 Ibid. of Judicial Sovereignty' (2019) ICL Journal, 373 (394). 
result in a highly fragmented constitutional jurisprudence and undermine legal certainty.

\section{The ECHR and War Crimes Cases in Former Yugoslavia: A Valuable Source?}

The issue of the KSC remaining outside the remit of the ECtHR's review deserves some further discussion. Since the former Yugoslav republics ratified the ECHR, ${ }^{98}$ the Strasbourg Court has decided a number of complaints regarding proceedings that are directly or indirectly linked to the armed conflicts in Yugoslavia in the 1990s. Some of the issues arising in these cases may surface in the proceedings before the KSC. As discussed above, complainants challenging the decisions of the KSC will not have recourse to ECtHR and the judges of the Specialist Chambers will have the final say on the matter.

The Strasbourg Court, it must be noted, does not shy away from addressing the particular challenges of large-scale human rights violations committed in armed conflict. The Court is increasingly engaged in what can be termed a judicial dialogue with international and internationalised criminal courts as well as domestic courts dealing with core crimes in State Parties. One example common to this area is the question of applicable law, specifically the question of lex mitior and retrospective application of domestic penal codes. In Maktouf and Damjanovic v. Bosnia, the ECtHR ruled that the retroactive application of post-war penal codes in Bosnia could have operated to the perpetrators' disadvantage, resulting in the imposition of a heavier penalty and therefore violating Article 7 of the ECHR. ${ }^{99}$ The ECtHR was also seized of a complaint contesting the involvement of international judges in adjudicating war crime cases in domestic courts, and dismissed challenges to their independence and professionalism. ${ }^{100}$ Another common issue arising in the context of war crimes prosecutions is the contention of the lack of effective investigation into disappearances

98 Slovenia: 1994, North Macedonia: 1997, Croatia: 1997, Bosnia: 2002, Serbia: 2004, Montenegro: 2004.

99 ECtHR, Judgment (GC), 18 July 2013, Maktouf and Damjanović v Bosnia and Herzegovina, Application Nos. 2312/08 and 34179/08, paras. $72 \mathrm{ff.}$

100 Id., para. 51. 
and deaths. In several cases, the ECtHR found a violation of Article 2 (right to life) based on inadequate domestic investigations. ${ }^{101}$

This jurisprudence of the ECtHR shows the range and effectiveness of the Convention's response to allegations of human rights violations committed in or in relation to armed conflict. The Strasbourg Court is able and willing to supervise States in the fulfilment of their undertakings when redressing international crimes and other large-scale human rights violations, and the possibility of this last resort control would also be beneficial for the Kosovo Specialist Chambers.

\section{F. Conclusion}

The multifaceted role of the ECHR in Kosovo serves as an example of the Convention's potential to influence human rights protection in nonState Parties and to impact the international human rights discourse more generally. In Kosovo, two factors were decisive in this regard: first, the intervention of the international community, specifically the UN, that initially introduced the ECHR into Kosovo's legal system, and second, the constitutional choices that subsequently embedded the Convention within its territory.

Because of the international community's decision to tie Kosovo's emerging constitutional framework to internationally recognised human rights standards, the Convention and its Protocols, along with a handful of other international human rights instruments, are now firmly entrenched in the Kosovo Constitution and given priority over domestic laws. Moreover, the Constitution also prescribes that all human rights and fundamental freedoms guaranteed by it must be interpreted in accordance with the decisions of the Strasbourg Court. The continuing support from the international community, especially the CoE, helps strengthen Kosovo's domestic capacity to respect and protect human rights and fundamental freedoms and is in line with the principle of subsidiarity.

Whilst generally a very positive development, the system has its limitations. Since Kosovo is not a State Party to the Convention, there is no recourse to the ECtHR. This has caused the domestic courts - notably the Constitutional Court - to assume the role of the final authority when it

101 ECtHR, Judgment, 20 January 2011, Jularić v Croatia, Application No. 20106/06; ECtHR, Judgment, 20 January 2011, Skendžić and Krznarić v Croatia, Application No. $16212 / 08$. 
comes to interpreting the Convention for Kosovo complainants, which is not without its challenges. The conclusion that can be drawn is that while it is possible for a treaty (ECHR) to be implemented and assume a vital role in a non-State Party, the system of protection lacks an international monitoring and enforcement element (ECtHR) in order to reach its full potential.

The ECHR has also proved instrumental in the adjudication of international and trans-national crimes in the internationalised judicial mechanisms in Kosovo, first under the UNMIK and EULEX umbrella, and more recently within the Kosovo Specialist Chambers. In the context of the latter, the Convention is, by virtue of its status in the Constitution, a directly applicable source of law. As the judicial proceedings at the KSC unfold, it will be interesting to observe what implications, if any, will direct applicability of the ECHR have in comparison to, for example, the proceedings of ad hoc criminal tribunals and the International Criminal Court, where the Convention is often referenced by the parties and the judges but is not as such a direct source of rights and obligations. Finally, the Convention has been and remains instrumental in considering alleged violations of human rights by international actors in Kosovo through the operation of the human rights review panels within UNMIK and EULEX.

In sum, this chapter has attempted to provide an overview of the curious relationship between the ECHR and Kosovo in the last two decades. This relationship, as can be seen from the above, is not static and continues to evolve. In the future we may see Kosovo joining the $\mathrm{CoE}$ and becoming a State Party to the Convention. We may then come to no longer speak of a curious relationship between the two.

\section{Bibliography}

Arai-Takahashi, Yutaka: The Margin of Appreciation Doctrine and the Principle of Proportionality in the Jurisprudence of the ECHR (2002).

Carozza, Paolo G.: Subsidiarity as a Structural Principle of International Human Rights Law, Am. J. Int'l L. 2003, 38ff.

Constitutional Court of Kosovo: Annual Report 2009, 20 December 2009, https://gj k-ks.org/wp-content/uploads/2017/11/RaportiVjetor2009Final_ANG.pdf.

Constitutional Court of Kosovo: Newsletter (2021), https://gjk-ks.org/en/publicatio n_category/newsletter/.

De Hert, Paul/Korenica, Fisnik: The New Kosovo Constitution and Its Relationship with the European Convention on Human Rights: Constitutionalization "Without" Ratification in Post-Conflict Societies, ZaöRV 2016, $143 f f$. 
Dzehtsiarou, Kanstantsin/Tzevelekos, Vassilis P.: The Conscience of Europe that Landed in Strasbourg: A Circle of Life of the European Court of Human Rights, ECHRLR 2020, $1 \mathrm{ff}$.

Glenny, Misha: The Fall of Yugoslavia: The Third Balkan War (1996).

Harmsen, Robert: The European Convention on Human Rights After Enlargement, Int'l J Human Rts 2001, 18ff.

Hasani, Enver: The Role of the Constitutional Court in the Development of the Rule of Law in Kosovo, RCEEL 2018, 274ff.

Hasani, Enver/Mjeku, Getoar: International(ized) Constitutional Court: Kosovo's Transfer of Judicial Sovereignty, ICL Journal 2019, $373 \mathrm{ff}$.

Helfer, Laurence R.: Redesigning the European Court of Human Rights: Embeddedness as a Deep Structural Principle of the European Human Rights Regime, EJIL 2008, 125ff.

Human Rights Review Panel: Annual Report (2010), https:/hrrp.eu/annual-report. php.

Human Rights Review Panel: Table of Cases with Follow-Up Decisions - April 2020 (2010), https://hrrp.eu/Statistics.php.

Istrefi, Remzije: Evolving International Practices for Protection of Human Rights the UN Human Rights Advisory Panel and EU Human Rights Review Panel, AUDJ 2017, 60 ff.

Karčić, Fikret: A Study on Legal Formalism in the Former Yugoslavia and its Successor States (2020), https://cids.no/wp-content/uploads/pdf/cids-reports/100 16-cids-rapport-2020.pdf.

Knoll, Bernhard/Uhl, Robert-Jan: Too Little, Too Late: the Human Rights Advisory Panel in Kosovo, European Human Rights Law Review 2007, 534ff.

Korenica Fisnik/Doli, Dren: Taking Care of Strasbourg: The Status of the European Convention on Human Rights and the Case-Law of the European Court of Human Rights in Kosovo's Domestic Legal System, Liverpool Law Rev 2011, 209ff.

Korenica, Fisnik/Zhubi, Argjend/Doli, Dren: The EU-engineered hybrid and international specialist court in Kosovo: how "special" is it? EuConst 2016, 474ff.

Kosovo Specialist Chambers \& Specialist Prosecutor's Office: 2021, https://www.sc p-ks.org/en.

Ministry of Foreign Affairs and Diaspora of the Republic of Kosovo: International recognitions of the Republic of Kosovo (2018), https:/www.mfa-ks.net/en/politi ka/483/njohjet-ndrkombtare-t-republiks-s-kosovs/483.

Office of the UN High Commissioner for Human Rights: Civil Society Report on Human Rights in Kosovo in 2019, June 2020, https://www.ohchr.org/Document s/Press/kosovo_cso_2019_human_rights_report_en.pdf.

Silber, Laura/Little, Allan: Yugoslavia: Death of a Nation (1997). 
UN Security Council: Letter Dated 26 March 2007 from the Secretary-General addressed to the President of the Security Council, Addendum, Comprehensive Proposal for the Kosovo Status Settlement, UN Doc. S/2007/168/Add.1, 26 March 2007.

UN Security Council: Military-technical agreement between the international security force (KFOR) and the Governments of the Federal Republic of Yugoslavia and the Republic of Serbia, UN Doc. S/1999/682, 15 June 1999.

UNMIK: The Human Rights Advisory Panel: History and Legacy, Kosovo, 20072016, Final Report, 30 June 2016, https:/unmik.unmissions.org/sites/default/file s/hrap_final_report_final_version_30_june_2016.pdf.

Van de Heyning, Catherine: Constitutional Courts as Guardians of Fundamental Rights. The constitutionalisation of the Convention through domestic constitutional adjudication, in: Popelier, Patricia/Mazmanyan, Armen/Vandenbruwaene, Werner (eds), The Role of Constitutional Courts in Multilevel Governance (2012), 19 ff.

Williams, Sarah: Hybrid and Internationalised Criminal Tribunals - Selected Jurisdictional Issues (2012).

Williams, Sarah: The Specialist Chambers of Kosovo: The Limits of Internationalization?, JICJ 2016, $25 \mathrm{ff}$. 
